\title{
Bloom of the marine diazotrophic cyanobacterium Trichodesmium erythraeum in the Northwest African Upwelling
}

\author{
Antonio G. Ramos ${ }^{1, *}$, Antera Martel ${ }^{2}$, Geoffrey A. Codd ${ }^{3}$, Emilio Soler ${ }^{2}$, Josep Coca ${ }^{1}$, \\ Alex Redondo ${ }^{1}$, Louise F. Morrison ${ }^{3}$, James S. Metcalf ${ }^{3}$, Alicia Ojeda ${ }^{4}$, Sonia Suárez ${ }^{2}$, \\ Michel Petit ${ }^{5}$ \\ ${ }^{1}$ SEASnet Canarias, Dpto. de Biología, University of Las Palmas de Gran Canaria, Campus de Tafira, \\ 35017 Las Palmas de Gran Canaria, Canary Islands, Spain \\ ${ }^{2}$ National Bank of Algae, Centro de Biotecnología Marina, Muelle de Taliarte s/n 35214-Telde (Gran Canaria), \\ Canary Islands, Spain \\ ${ }^{3}$ Division of Applied and Environmental Biology, School of Life Sciences, University of Dundee, Dundee DD1 4HN, UK \\ ${ }^{4}$ Instituto Canario de Ciencias Marinas (ICCM), Carretera de Taliarte s/n, PB 56. 35200 Telde (Gran Canaria), \\ Canary Islands, Spain \\ ${ }^{5}$ SEASnet Montpellier, Institut de Recherche pour le Développement (IRD), Maison de la Télédétection, 500 Rue JF Breton, \\ 34093 Montpellier Cedex 05, France
}

\begin{abstract}
A bloom of the non-heterocystous diazotrophic cyanobacterium Trichodesmium erythraeum Ehrenberg is reported in the Canary Islands Archipelago during August of 2004, the warmest period of a meteorological series recorded by the National Institute of Meteorology (Spain) since 1912. Samples showed massive occurrences of T. erythraeum (1000 filaments $\left.\mathrm{ml}^{-1}\right)$ in different sectors of northern and southern waters off the central Canary Islands. Water analyses also showed a relatively low presence of dinoflagellates and diatoms. Quasi-true colour satellite images of dust storms, elevated sea surface temperature (the warmest satellite-derived record), chlorophyll $a$ and geostrophic current fields showed satellite-derived optical positives of Trichodesmium in an African upwelling advective, jet-drifting westward current off the south Canary Islands. Analyses for cyanotoxins using HPLC found microcystins, which was confirmed by immunoassay, at concentrations from 0.1 to $1.0 \mathrm{\mu g}$ microcystin-LR equivalents $\left(\mathrm{g}^{-1} \mathrm{dry}\right.$ weight of bloom material). A $T$. erythraeum bloom such as that observed in August 2004 in the NW African Upwelling does not appear to have been recorded for the area previously. The bloom may have developed due to the exceptionally warm weather and/or to the massive dust storms from the Sahara Desert observed in the NE Atlantic in August 2004.
\end{abstract}

KEY WORDS: Cyanobacteria · Trichodesmium erythraeum • Remote sensing · NW African Upwelling · Advective jet · Toxicity

During the warmest summer reported by the National Institute of Meteorology for Spain (INM Spain) in the Canary Islands since 1912, satellite and in situ observations in August 2004 detected an extensive bloom of the diazotrophic cyanobacterium Trichodesmium erythraeum Ehrenberg, which has never been detected in the NW African Upwelling and adjacent areas before (Capone et al. 1997, Lenes et al. 2001, Hood et al. 2002).

At the end of July 2004, quasi-true-colour images from the OrbView-2 SeaWIFS satellite revealed con- 

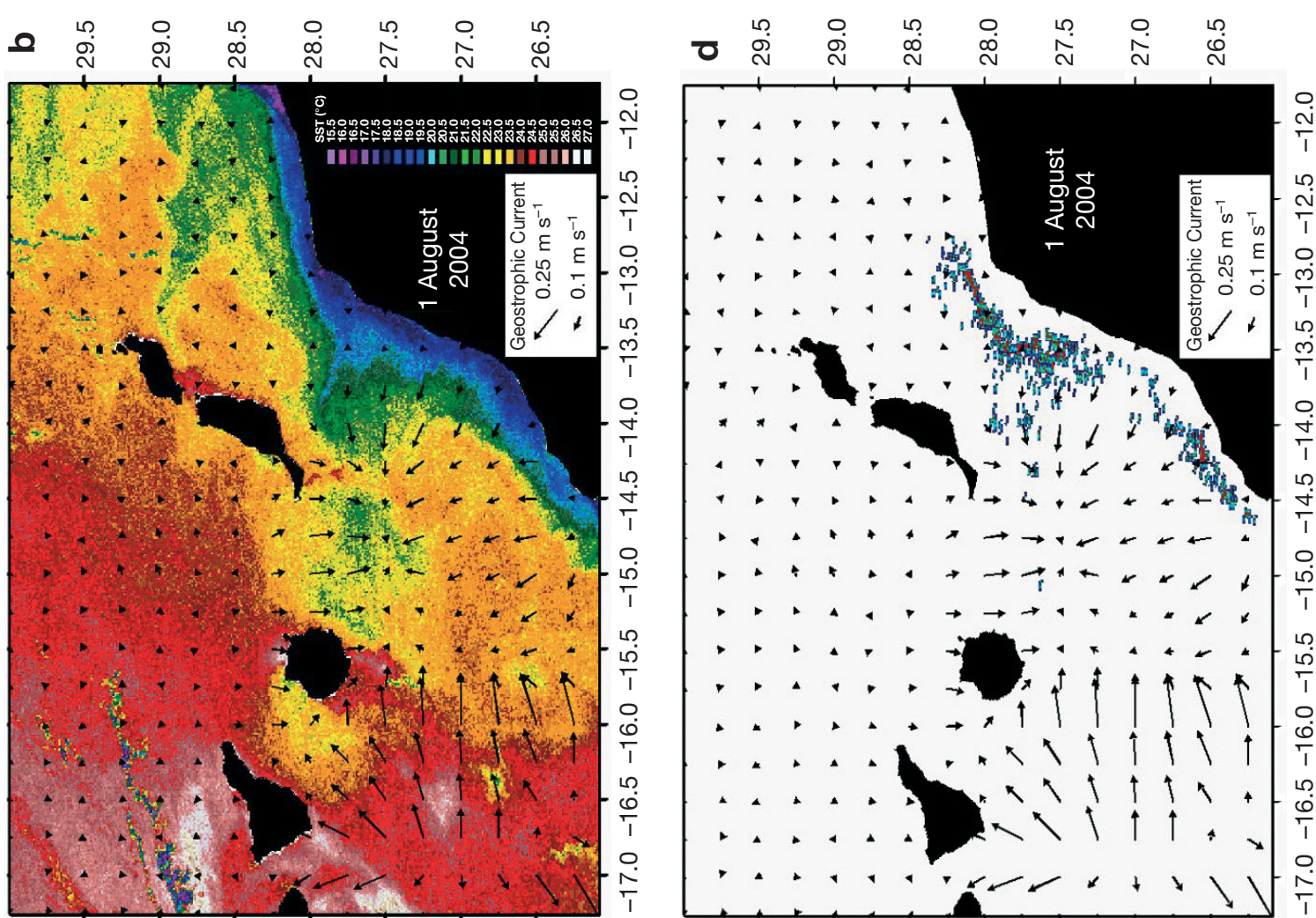

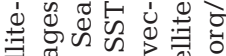
ब.

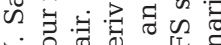
उ응 일

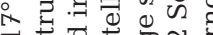
0

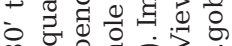

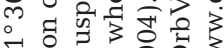
$\because$ in 0 क

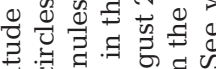

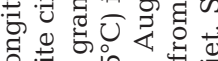
青:

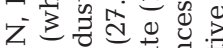

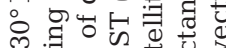

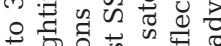

舟

늘

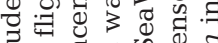

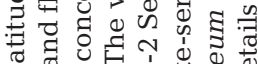

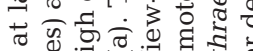

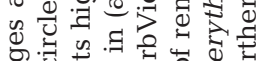
Oت

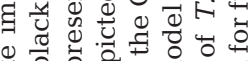

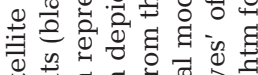

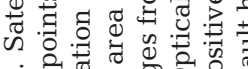

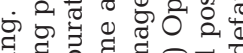

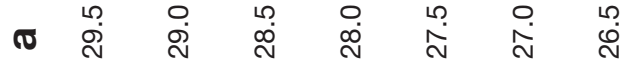

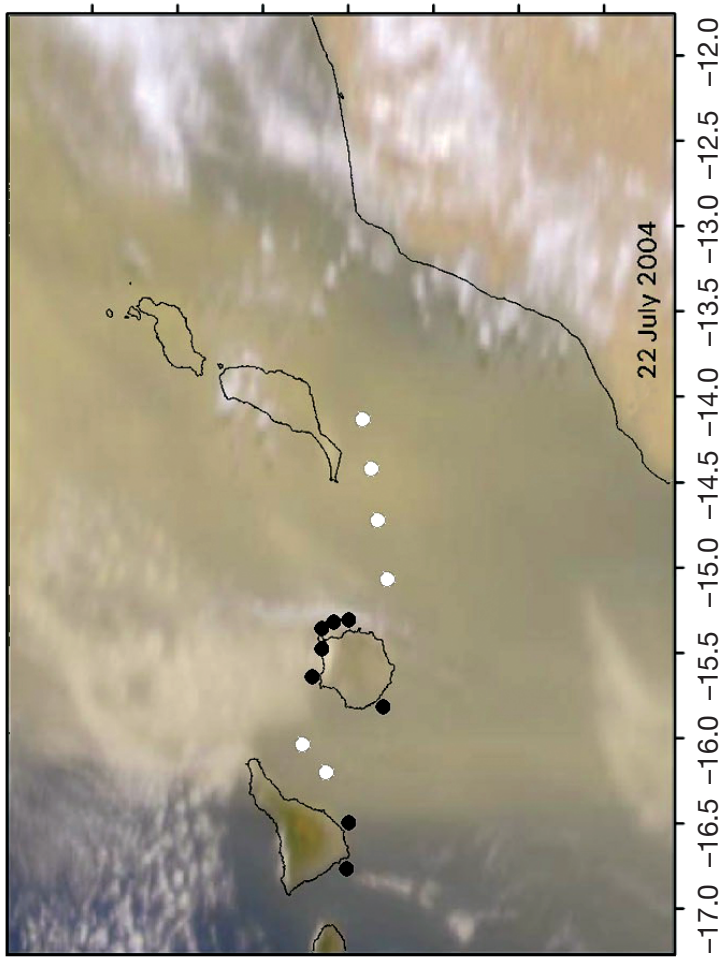

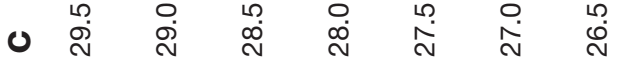

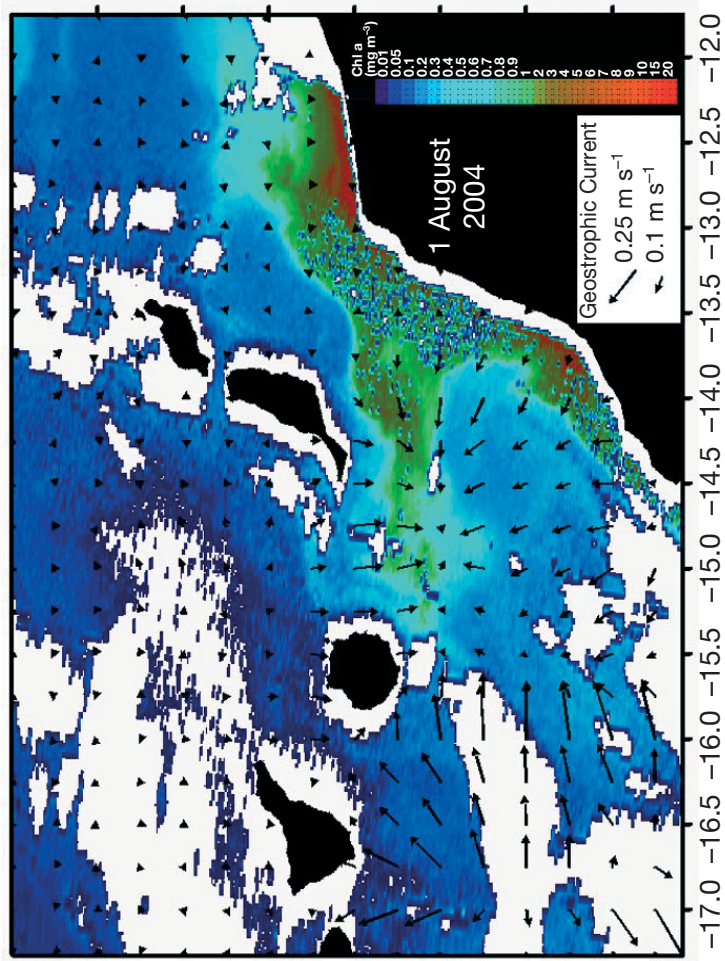

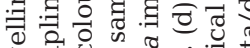

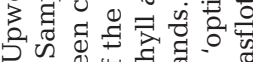

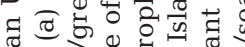

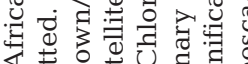

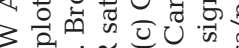

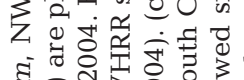

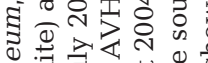

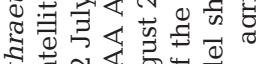

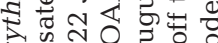

के

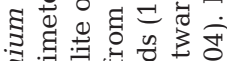

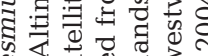

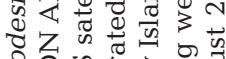

वृ की

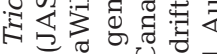

पे है

व

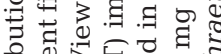

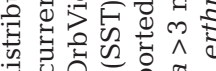

浣 0

诸

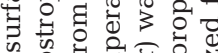

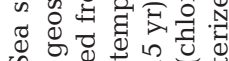

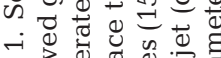

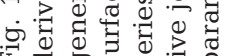


current dust storms from the Sahara Desert which covered the NE Atlantic area (Fig. 1a). In this area, the annual average dry flux of Saharan dust can range from 0.03 to $0.08 \mathrm{~g} \mathrm{~m}^{-2} \mathrm{~d}^{-1}$ or $1.7 \times 10^{6}$ tons $\mathrm{yr}^{-1}$ as inferred from experimental dry deposition (Torres et al. 2002). Dust fluxes produce a significant impact on the biogeochemical cycle of trace elements, providing a source of the Fe required for diazotrophic heterocystous and non-heterocystous cyanobacterial growth due to the demand for nitrogenase (Capone et al. 1997, Lenes et al. 2001).

Beginning in August, satellite-derived AVHRR/NOAA sea surface temperature (SST) images recorded $28.5^{\circ} \mathrm{C}$, the warmest record within the last $15 \mathrm{yr}$ in Canary Island waters. SST imagery also detected convergent warm $\left(23^{\circ} \mathrm{C}\right)$ oceanic waters over the NW African shelf where the upwelling originates (Fig. 1b). Chlorophyll a images from the OrbView-2 SeaWIFS satellite showed richly productive coastal upwelled waters (chl $a>3 \mathrm{mg}$ $\mathrm{m}^{-3}$ ) of an advective jet at an anomalously warmer SST $\left(24.5^{\circ} \mathrm{C}\right)$ compared to the normal SST for upwelled waters (i.e. 18 to $22^{\circ} \mathrm{C}$ ). The jet was observed from satellite-derived geostrophic current field pictures of the CLS-AVISO Altimeter Satellite Data Centre, and advected westward with the offshore-directed surfacecurrent drift fields to reach the position and configuration seen in Fig. 1c.

An optical model of water leaving radiance images from the OrbView-2 SeaWIFS satellite parameterized for Trichodesmium (Hood et al. 2002) was tested during the bloom event (Fig. 1d). The model detected significant remote-sensed optical positives of Trichodesmium in the NW African shelf. It also showed optical positives in the advective jet drifting westward off the south Canary Islands.

Subsurface water samples (2 l) were collected around the seashore at different locations off the islands off Gran Canaria and Tenerife during August 2004. Samples were fixed in $1 \%$ Lugol's Iodine immediately and trichomes were counted after a $24 \mathrm{~h}$ settling period. Cyanobacteria were identified according to Anagnostidis \& Komàrek (1998). Concentrations of heterocystous and non-heterocystous cyanobacteria, together with other phytoplankton counts, were carried out with an inverted microscope using the Utermöhl technique. Results showed the absence of heterocystous diazotrophic cyanobacteria. Ninety-seven percent of the cells consisted of the non-heterocystous diazotrophic cyanobacterium Trichodesmium erythraeum (1240 filaments $\left.\mathrm{ml}^{-1}\right)$. The remaining cells (10 cells $\mathrm{ml}^{-1}$ ) consisted of dinoflagellates and diatoms (Gymnodinium, Ostreopsis and Zygabikodinium). The high water temperatures may have accounted for the dominance of the bloom by $T$. erythraeum, rather than by heterocystous diazotrophic cyanobacteria. Indeed, differences in temperature-dependent $\mathrm{O}_{2}$ flux activity, respiration and of $\mathrm{O}_{2}$-sensitive nitrogen fixation appear to favour the diazotrophic growth of Trichodesmium at elevated temperatures, rather than that of heterocystous cyanobacteria (Staal et al. 2003).

In order to determine environmental and health impacts of the Trichodesmium erythraeum blooms off the Canary Islands the cyanotoxins were analysed: microcystins by means of HPLC and immunoassay, and anatoxin-a and cylindrospermopsin by HPLC (Metcalf et al. 2000, Codd et al. 2001). Anatoxin-a and cylindrospermopsin were not detectable, but microcystins were found by HPLC, with photodiode array detection, with confirmation by immunoassay at concentrations from 0.1 to $1.0 \mu \mathrm{g}$ microcystin-LR equivalents ( $\mathrm{g}^{-1}$ dry weight of bloom material).

Such Trichodesmium erythraeum blooms have apparently not been recorded previously anywhere along the coast bordering the NW African Upwelling. Reliable satellite observations and verification on the ground have confirmed that the early stages of this anomalous event are associated with the exceptionally warm weather and dust storms observed in this area in August 2004. This phenomenon may be an increasingly observed characteristic of higher temperatures (global warming), with consequent increases in primary production and $\mathrm{N}_{2}$ fixation, which may be accompanied by bloom toxicity.

\section{LITERATURE CITED}

Anagnostidis K, Komárek J (1988) Modern Approach to the classification system of Cyanophytes. 3-Oscillatoriales. Algol Stud 50-53:327-472

Capone DG, Zehr JP, Paerl HW, Bergman B, Carpenter EJ (1997) Trichodesmium a globally significant marine cyanobacterium. Science 276:1221-1229

Codd GA, Metcalf JS, Ward CJ, Beattie KA, Bell SG, Kaya K, Poon GK (2001) Analysis of cyanobacterial toxins by physicochemical and biochemical methods. J AOAC Int 84:1626-1635

Hood RR, Subramaniam A, May LR, Carpenter EJ, Capone DG (2002) Remote sensing of nitrogen fixation by Trichodesmium. Deep-Sea Res II 49:23-147

Lenes J, Darrow B, Cattrall C, Heil CA and 7 others (2001) Iron fertilization and the Trichodesmium response on the West Florida shelf. Limnol Oceanogr 46:1261-1277

Metcalf JS, Bell SG, Codd GA (2000) Production of novel polyclonal antibodies against the cyanobacterial toxin microcystin-LR and their application for the detection and quantification of microcystins and nodularin. Water Res 34:2761-2769

Staal M, Meysman FJR, Stal LJ (2003) Temperature excludes $\mathrm{N}_{2}$-fixing heterocystous cyanobacteria in the tropical oceans. Nature 425:504-507

Torres M, Gelado M, Collado C, Siruela V, Cardona P, Hernández-Brito J (2002) Variability of dust inputs to the CANIGO zone. Deep-Sea Res II 49:3455-3464 